University of Montana

ScholarWorks at University of Montana

1996

\title{
Pinus Ponderosa Seedling Establishment and the Influence of Competition with the Bunchgrass Agropyron Spicatum
}

Peter F. Kolb

University of Montana - Missoula, peter.kolb@umontana.edu

Ronald Robberecht

Follow this and additional works at: https://scholarworks.umt.edu/forest_pubs

Part of the Forest Management Commons

Let us know how access to this document benefits you.

\section{Recommended Citation}

Kolb, Peter F. and Robberecht, Ronald, "Pinus Ponderosa Seedling Establishment and the Influence of Competition with the Bunchgrass Agropyron Spicatum" (1996). Forest Management Faculty Publications. 28.

https://scholarworks.umt.edu/forest_pubs/28

This Article is brought to you for free and open access by the Forest Management at ScholarWorks at University of Montana. It has been accepted for inclusion in Forest Management Faculty Publications by an authorized administrator of ScholarWorks at University of Montana. For more information, please contact scholarworks@mso.umt.edu. 


\title{
PINUS PONDEROSA SEEDLING ESTABLISHMENT AND THE INFLUENCE OF COMPETITION WITH THE BUNCHGRASS AGROPYRON SPICATUM
}

\author{
PETER F. KOLB AND RONALD ROBBERECHT ${ }^{1}$ \\ Department of Forest Resources, and Department of Range Resources, College of Forestry, Wildlife and Range Sciences, \\ University of Idaho, Moscow, Idaho 83844-1135
}

\begin{abstract}
Interspecific competition between Agropyron spicatum (Pursh.) Scrib. \& Smith bunchgrasses and naturally established seedlings of Pinus ponderosa was examined within a pine/bunchgrass community. A wire mesh was used to separate bunchgrass culms from pine seedling shoots to determine if the bunchgrass canopy influenced the survival of pine seedlings. In addition, two lengths of root exclusion tubes were used to determine the effects of bunchgrass root overlap on pine seedlings. The bunchgrass canopy did not significantly affect pine seedling survival. However, root competition, presumably for water, significantly decreased pine seedling survival. Exclusion of bunchgrass roots from a 0.15-mand $0.30-\mathrm{m}$-deep root zone of pine seedlings resulted in $40 \%$ and $80 \%$ reductions in mortality, respectively. Root exclusion also significantly delayed mortality 2-3 wk. Pine seedlings developed taproots that reached below the zone of maximum bunchgrass root density within $4 \mathrm{wk}$ of germination. The pine/bunchgrass community is dominated by two species that utilize similar resource zones in the soil during the establishment of pine germinants in the bunchgrass understory. Interspecific competition tends to be greatest during this establishment stage and becomes reduced as pine seedlings grow and explore the deeper regions of the soil profile. In areas with shallow soils and an established bunchgrass understory, establishment of pine seedlings may occur successfully only if soil moisture is available in deeper soil horizons during the summer.
\end{abstract}

\section{Introduction}

Interspecific competition for limited resources can decrease growth and survival of species within a plant community and is an important process affecting plant community structure (Whittaker 1975; Harper 1977; Parrish and Bazzaz 1982; Tilman 1982; Newman 1983; Christy 1986; Miller and Werner 1987; Reichenberger and Pyke 1990). Use of limited resources by more competitive species can reduce resource availability for less competitive species (Tilman 1989) and may be especially pronounced when one species is in the seedling stage. In addition, early colonization and resource capture on sites with low productivity may exclude any new species or limit the growth and survival of existing species (Grime 1977, 1979). The detrimental effects of interspecific plant competition belowground for soil water, however, can be offset in some cases where shading by established vegetation may ameliorate the effects of intense solar radiation and associated high temperatures and evaporative demand limit plant function (Shreve 1931; Turner et al. 1966; Allen and Lee 1989; Belsky et al. 1989; Frost and McDougald 1989; Nobel 1989; Wilson 1989; Jacquart and Armentano 1992).

In semiarid and arid ecosystems of the western United States, plant competition for available soil water has been shown to influence species survival (Fonteyn and Mahall 1981; Robberecht et al. 1983; Allen and Allen 1986; Caldwell and Richards 1986; Caldwell 1988; Allen and Lee 1989; Gordon et al. 1989; Sala et al. 1989; Franco and Nobel 1990; Riegel et al. 1991), particularly when newly established seedlings compete

${ }^{1}$ Author for correspondence and reprints. Telephone 208-8857404; fax 208-885-6226; E-mail ronrobb@uidaho.edu.

Manuscript received November 1995; revised manuscript received March 1996. with established vegetation. Competition for water may also affect seedling survival on drier habitats within mesic forest ecosystems (Shainsky and Radosevich 1986, 1992; Peterson 1988). Associations of Pinus ponderosa (Dougl.) Lawson and Agropyron spicatum $^{2}$ (Pursh.) Scrib. \& Smith persist on the drier sites that form ecotones between forests and grasslands and as seral communities in more mesic forest communities (Daubenmire 1943, 1968; Smith 1985; Cooper et al. 1987). This community is characterized by an open pine overstory and a well-developed bunchgrass understory with few other plant species present.

Pinus ponderosa is unique among tree species of the northwestern United States because it can survive on xeric sites where other trees are unable to establish naturally. This includes more mesic sites when disturbance has removed the existing forest overstory and understory vegetation, thereby creating a hotter, drier microenvironment (Riegel et al. 1992). Pinus ponderosa is thought to occupy this ecological niche because of a greater adaptability to xeric conditions than other tree species (Smith 1985). Pinus ponderosa trees have been shown to survive in areas with low precipitation by maintaining high water use efficiencies and deep root systems that utilize water sources unavailable to other plants (Daubenmire 1968; Jackson and Spomer 1979; DeLucia et al. 1988; DeLucia and Heckathorn 1989; DeLucia and Schlesinger 1991). These adaptations may also allow pine seedlings to establish in the highly competitive environment of a bunchgrass understory.

In northern Idaho spring germination of $P$. ponderosa seedlings on sites dominated by bunchgrasses is abundant, although few seedlings survive the environment of summer months (Cooper et al. 1987; P. F. Kolb

${ }^{2}$ Proposed name change to Pseudoroegneria spicata (Pursh) Löve subsp. spicata (Barkworth and Dewey 1985). 
and R. Robberecht, unpublished data). A primary cause of low seedling survival may result from interspecific competition for soil resources between bunchgrasses and tree seedlings. Species with fibrous root systems, such as $A$. spicatum, are better competitors for limited soil nutrients and particularly for mobile resources such as water (Caldwell and Richards 1986; Caldwell 1988; Eissenstat and Caldwell 1988; Gordon et al. 1989). We hypothesize that competition for soil resources, especially water, resulting from root overlap between pine seedlings and bunchgrasses limits pine seedling growth and survival. Alternatively, if tussocks of A. spicatum intercept a portion of the incoming solar radiation near newly established pine seedlings, these tussocks could ameliorate high soil surface and air temperatures that would otherwise be lethal to newly germinated pine seedlings. The objectives of this study were, therefore, to determine (1) the effects of belowground competition for water between A. spicatum and seedlings of $P$. ponderosa, (2) the relationship between pine seedling development and seasonal soil water availability, (3) the effects of depth of available soil water on seedling growth and carbon allocation, and (4) the influence of a bunchgrass overstory on the productivity and survival of pine seedlings.

\section{Material and methods}

\section{FIELD}

This study was conducted at Basalt Hill on the University of Idaho Experimental Forest $\left(46^{\circ} 52^{\prime} \mathrm{N}, 116^{\circ} 47^{\prime} \mathrm{W}, 1100 \mathrm{~m}\right.$ a.s.1.), $52 \mathrm{~km}$ northeast of Moscow, Idaho, in a seral Pinus ponderosa/Agropyron spicatum community composed of a mature $P$. ponderosa overstory of ca. 50 trees ha-1 with a bunchgrass understory interspersed with shrubs and herbs. The soil is a Uvi-Spokane association (Barker 1981) silt loam ca. $0.5 \mathrm{~m}$ in depth overlying decomposing granite.

During two consecutive summer seasons, 30 newly germinated pine seedlings were randomly chosen in a homogeneous 1-ha area on a south-facing $15^{\circ}$ slope. Three root treatments consisting of root exclusion tubes of multiple lengths (Cook and Ratcliff 1984; Snaydon and Howe 1986; Reichenberger and Pyke 1990) were used to exclude bunchgrass roots. For a control, 10 seedlings received no belowground manipulation and thus were exposed to root competition from bunchgrasses. For partial root competition, 0.15-m-long by $0.1-\mathrm{m}$-diameter stainless steel cylinders were inserted around another 10 pine seedlings. The majority of root competition from bunchgrasses was excluded by inserting $0.30-\mathrm{m}$-long by $0.1-\mathrm{m}$-diameter cylinders around the remaining 10 pine seedlings. The top of each cylinder was flush with the soil surface. Five seedlings from each of the three root treatments were randomly selected for the aboveground treatment, which consisted of a thin wire mesh placed around each pine seedling. This procedure separated bunchgrass culms from the pine seedling shoot within a 1 $\mathrm{m}^{2}$ area. The remaining 15 pine seedlings without any bunchgrass culm manipulation served as the control group. An additional and separate group of $24 P$. ponderosa seedlings located on the site were studied for root development over the growing season. Root development was determined biweekly by excavating three randomly selected seedlings. Pine seedlings that died in the root exclusion study were also excavated. The number of needles, needle length, and stem diameter were measured weekly for all seedlings. Foliage and root areas were measured using a digital image analysis system (Decagon DIAS II). In addition, bunchgrass shoot and root density, number of germinating pine seedlings, visually estimated percentage of cover, and attenuation of solar radiation by bunchgrass canopies were measured in the $1 \mathrm{~m}^{2}$ area around each selected seedling. Photosynthetically active radiation (PAR, 400-700 $\mathrm{nm}$ ) was measured with a LI-COR model LI-190SA quantum sensor.

Seedling height, number of live needles, and the mortality of seedlings within a $1 \mathrm{~m}^{2}$ area surrounding each treatment seedling were monitored weekly. Ambient soil water potential, soil water content, and temperature were also monitored weekly at three locations across the study site at depths of $0.05 \mathrm{~m}, 0.30 \mathrm{~m}$, and $0.5 \mathrm{~m}$ with soil psychrometers (Wescor Corp. model PCT-55) and by gravimetric analysis. These three soil depths represented depths of root competition for each treatment. Air temperature and relative humidity $0.2 \mathrm{~m}$ above the ground were measured continuously throughout the summer with a hygrothermograph (Bendix model 594), which was calibrated monthly with an Assmann psychrometer. Stomatal conductance was measured monthly between 0800 and 1000 with a steady state porometer (LI-COR model LI-1600). The Bonferroni $t$-procedure $(\alpha=0.05, c=3$ [Dunn 1961]) was used to determine significant differences among treatment means. Correlation analysis was performed to determine the relationship between water potential, stomatal conductance for pine needles, and seedling mortality.

\section{GREENHOUSE}

Five 1-yr-old $P$. ponderosa seedlings, obtained from the University of Idaho Experimental Nursery, were grown for 2 mo in 0.15 -m-diameter by $0.40-\mathrm{m}$ deep cylindrical containers filled with commercial potting soil. They were watered weekly and fertilized with a $100 \mathrm{ppm}$ solution of $\mathrm{N}$ P-K (20\%-20\%-20\% by mass) fertilizer. One month after the onset of needle growth, photosynthetic rates with respect to light level were determined for new foliage by enclosing seedling shoots in a cuvette attached to an open flow gas exchange system (Bingham et al. 1980) connected to an infrared gas analyzer (ADC model 225MK3) under a constant temperature of $25^{\circ} \mathrm{C}$ and a vapor density of $12 \mathrm{~g} \mathrm{~m}^{-3}$.

In addition, $25 P$. ponderosa seedlings were planted shortly after germination in polystyrene cylinders $0.06 \mathrm{~m}$ diameter by $1.0 \mathrm{~m}$ in length and filled with washed sand to determine the influence of available water depth on stomatal conductance and seedling carbon allocation. Supplemental lighting was provided by metal halide lamps that produced a combined lamp and sun irradiance of $700 \mu \mathrm{mol} \mathrm{m} \mathrm{m}^{-2} \mathrm{~s}^{-1}$ or greater over a 12 -h photoperiod. All containers were initially watered to near saturation with a $500 \mathrm{ppm}$ solution of N-PK (20\%-20\%-20\% by mass) fertilizer. Seedlings were then monitored for root growth by randomly choosing one seedling every week and excavating the root system. After seedling roots had penetrated the entire 1-m length of the container ( $3 \mathrm{wk}$ ), each of the 21 seedlings was randomly assigned to one of three treatments, consisting of a surface water supply only (top one-third of the container), $0.30-\mathrm{m}$ water supply only (middle third), or 0.9 -m water supply only (bottom third). From preliminary studies, we determined that $100 \mathrm{~mL}$ of water injected through a small hole in the container wall would be entirely held by the sand matric suction in a $0.3-\mathrm{m}$ section of the container. Stomatal conductance for whole seedlings was measured every other day at 10:00 


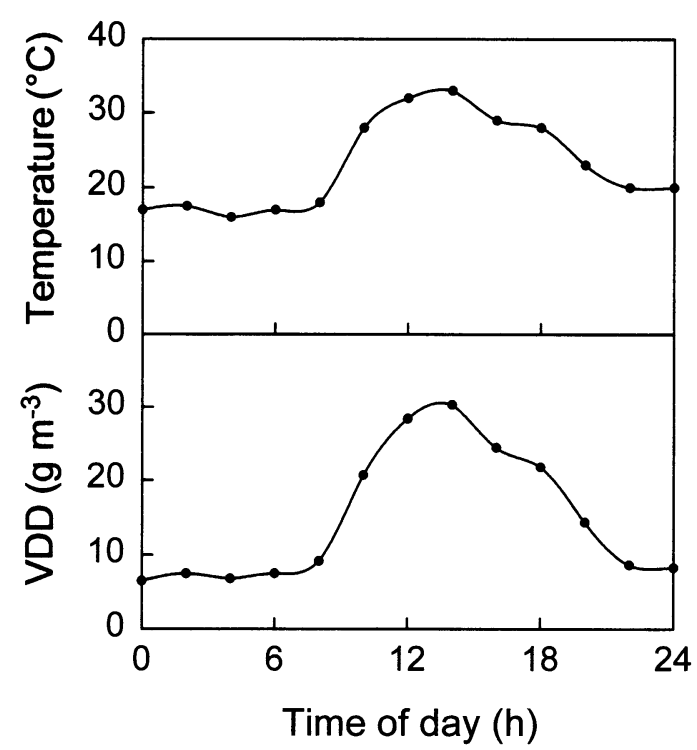

Fig. 1 Mean July-August diel temperatures and vapor density deficits $(V D D) 0.20 \mathrm{~m}$ above the soil surface of the field study. Each point represents the mean of 20 samples, with standard errors of the mean ranging from $2.6 \%$ to $4.3 \%$.

A.M. to determine seedling water stress. When the majority of the seedlings exhibited a $75 \%$ reduction in stomatal conductance, which had been previously determined to indicate imminent death, all seedlings were given $100 \mathrm{~mL}$ of water at their respective treatment depths. This process was followed through four watering cycles over 4 mo. Projected leaf area and leaf dry biomass, and root length and dry biomass in 0.3-m depth increments were determined at the end of the experiment. Differences in the means of shoot biomass, root biomass, and root biomass distribution were compared using the Bonferroni $t$-procedure $(\alpha=0.05)$.

\section{Results}

\section{FIELD}

The density of newly germinated seedlings of Pinus ponderosa on the $301-\mathrm{m}^{2}$ plots ranged from 0 to 25 seedlings $\mathrm{m}^{2}$ in early June of each season with an overall average of two seedlings $\mathrm{m}^{-2}$. During this period, a mean of $102 \pm 10$ live bunchgrass culms $\mathrm{m}^{-2}$ accounted for $30 \%-40 \%$ of the surface cover, while other herbaceous species had a cover of only $5 \%$. Approximately $50 \%$ of the space between plants was bare soil and 50\% was covered with sparse $P$. ponderosa needle litter.

Summer air temperatures at $0.2 \mathrm{~m}$ above the soil surface had a mean daily amplitude of $15^{\circ} \mathrm{C}$ and mean vapor density deficits during midday of $30 \mathrm{~g} \mathrm{~m}^{-3}$ (fig. 1). The water potential in the upper $0.05 \mathrm{~m}$ of soil decreased to less than $-1.5 \mathrm{MPa}$ in early July, while the water potentials for soils at depths of $0.25 \mathrm{~m}$ and $0.5 \mathrm{~m}$ remained above $-1.5 \mathrm{MPa}$ until late July and mid-August, respectively (fig. 2A).

Pinus ponderosa seedlings developed a single taproot exceeding $0.3 \mathrm{~m}$ in length within $4 \mathrm{wk}$ of germination. Soil water potential was greater than -0.03

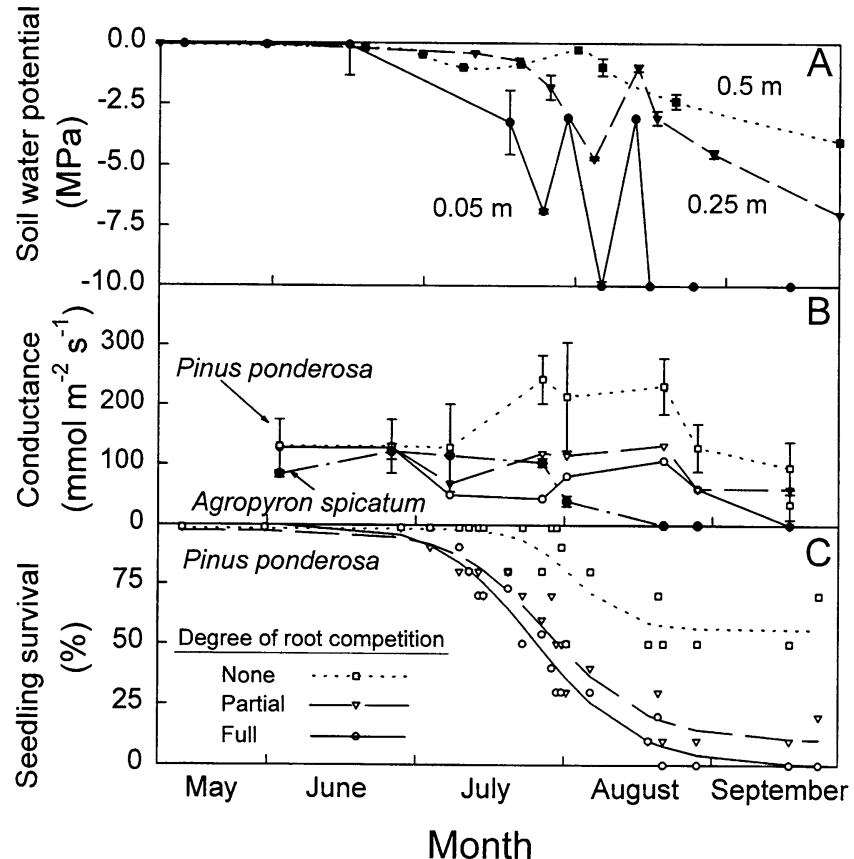

Fig. $2 A$, Mean seasonal change in mean soil water potential at three different depths ( $n=6$ per point). B. Mean stomatal conductance between three pine seedling root competition treatments and established bunchgrass ( $n=20$ per point). Vertical lines on graphs $A$ and $B$ represent 1 standard error of the mean. $C$, Mean seasonal pine seedling survival for three root competition treatments $(n=10$ seedlings per point).

MPa during this period of time. Seedling shoots that developed within 2-4 wk of germination generally had $5 \pm 1$ cotyledons, $33.5 \pm 1.1$ single juvenile needles, and a height of $0.08 \pm 0.03 \mathrm{~m}$. During the following 4 mo pine seedling shoots showed no significant height growth but increased from 1 to $3 \mathrm{~mm}$ in stem diameter. Total needle area, including cotyledons, during this period declined from $920 \pm 105 \mathrm{~mm}^{2}$ to $530 \pm 75 \mathrm{~mm}^{2}$ from needle senescence. A mean root: total plant biomass ratio of $0.78 \pm 0.11$ was observed after 4 mo.

Agropyron spicatum initiated growth in April, 1-2 mo before germination of pine seedlings, and ceased growing by the end of July. Dormancy, as evidenced by decreased stomatal conductance and increased foliage senescence, occurred during the first week in $\mathrm{Au}-$ gust and coincided with sharp decreases in soil water potential in the upper $0.25 \mathrm{~m}$ of soil (fig. $2 A, B$ ).

The fibrous root system of $A$. spicatum was concentrated in the upper $0.3 \mathrm{~m}$ of soil (fig. 3). The roots of $P$. ponderosa seedlings accounted for only $3 \%$ of the total root biomass in the soil volume extending $25 \mathrm{~mm}$ radially and $150 \mathrm{~mm}$ deep around each seedling. Roots of $A$. spicatum accounted for $97 \%$ of the biomass in this soil volume. Seedling mortality and stomatal conductance were significantly correlated with decreasing soil water potential (table 1). Pinus ponderosa seedlings exposed to full-root competition exhibited nearly $100 \%$ mortality within the first 4 mo of growth. Seedlings with roots shielded by $0.15-\mathrm{m}$ - and $0.30-\mathrm{m}$-long 


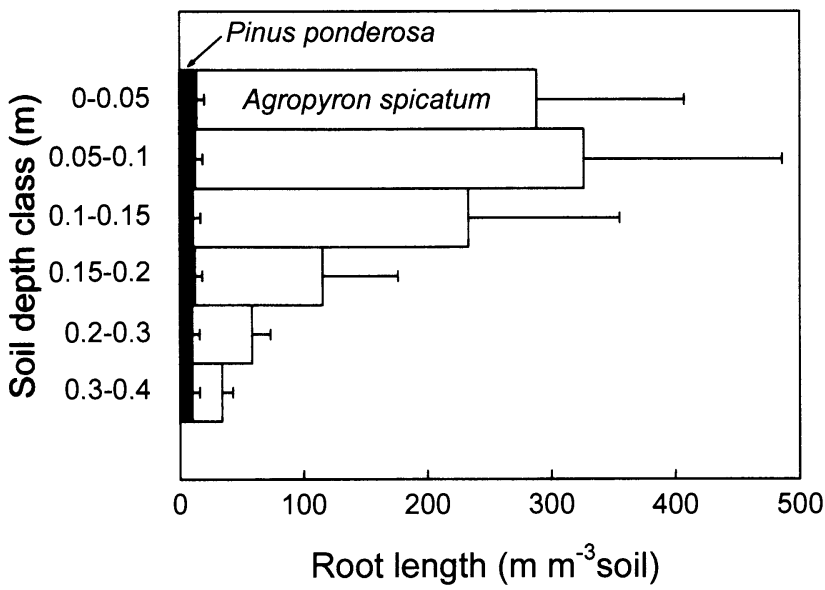

Fig. 3 Pattern of root distribution in 0.05-m depth increments for Pinus ponderosa seedlings and established Agropyron spicatum tussocks. Each bar represents the mean of 15 samples \pm 1 standard error of the mean.

exclusion tubes experienced significantly delayed and lower mortality of $80 \%$ and $40 \%$, respectively (fig. $2 C$ ). Stomatal conductance was significantly higher, by $50 \%$, for seedlings with no root competition as compared to the other two treatments during July and August (fig. 2B).

The bunchgrass overstory around $P$. ponderosa seedlings did not significantly affect growth, stomatal conductance, or survival. Levels of PAR at solar noon indicated a nonsignificant reduction of $10 \%$ (from 2000 to $1800 \mu \mathrm{mol} \mathrm{m} \mathrm{m}^{-2} \mathrm{~s}^{-1}$ ) in solar radiation from the A. spicatum canopy.

\section{GREENHOUSE}

Photosynthetic light response curves for $P$. ponderosa seedlings indicated that the compensation point for $\mathrm{CO}_{2}$ fixation occurred at a light level of approximately $70 \mu \mathrm{mol} \mathrm{m} \mathrm{m}^{-2} \mathrm{~s}^{-1}$ and that seedlings reached light saturation at 500-600 $\mu \mathrm{mol} \mathrm{m} \mathrm{m}^{-2} \mathrm{~s}^{-1}$ (fig. 4). Seedlings grown in 1-m-deep containers with three different

\section{Table 1}

CORRELATION COEFFICIENTS BETWEEN SEEDLING MORTALITY AND AMBIENT SOIL WATER POTENTIALS AT THREE DEPTHS, AND SEEDLING STOMATAL CONDUCTANCE

\begin{tabular}{|c|c|c|c|}
\hline & \multicolumn{3}{|c|}{$\begin{array}{l}\text { Mortality of Pinus } \\
\text { ponderosa seedlings with } \\
\text { roots exposed to three } \\
\text { levels of competition }\end{array}$} \\
\hline & Full & Partial & None \\
\hline \multicolumn{4}{|l|}{ Water potential at soil depth $(\mathrm{m})$ : } \\
\hline 0.05 & 0.87 & 0.85 & 0.72 \\
\hline 0.25 . & 0.82 & 0.82 & 0.71 \\
\hline 0.50 & 0.72 & 0.72 & 0.63 \\
\hline Stomatal conductance $\left(\mathrm{mmol} \mathrm{m} \mathrm{m}^{-2} \mathrm{~s}^{-1}\right) \ldots$ & 0.82 & 0.83 & 0.80 \\
\hline
\end{tabular}

Note. All showed significant correlations $(\alpha \leq 0.05)$. Mortality for seedlings without root competition had the lowest correlations with measured soil water potentials.

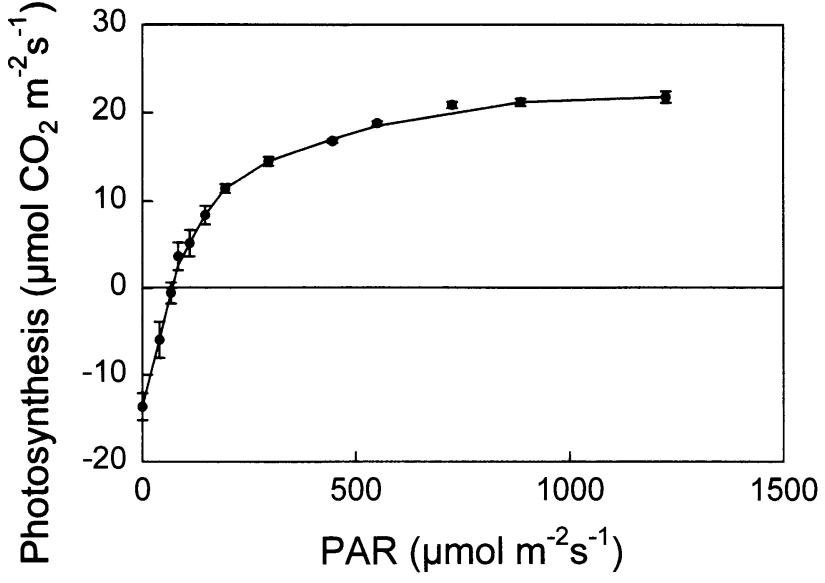

Fig. 4 Photosynthetic light response curve for Pinus ponderosa seedlings. Light saturation of photosynthesis occurred at approximately $600 \mu \mathrm{mol} \mathrm{m} \mathrm{m}^{-2} \mathrm{~s}^{-1}$. Each point represents the mean of four measurements with standard errors ranging from 2.3 to $0.20 \mu \mathrm{mol}$ $\mathrm{m}^{-2} \mathrm{~s}^{-1}$

depths of soil water recharge showed no significant differences in total biomass production after 4 mo. Root biomass and length were significantly greater in the watered container zones than the unwatered zones (fig. 5). Seedlings in all treatments developed $1.0-\mathrm{m}-$ long taproots within $4 \mathrm{wk}$ and maintained a root system throughout the entire container regardless of the depth of watering.

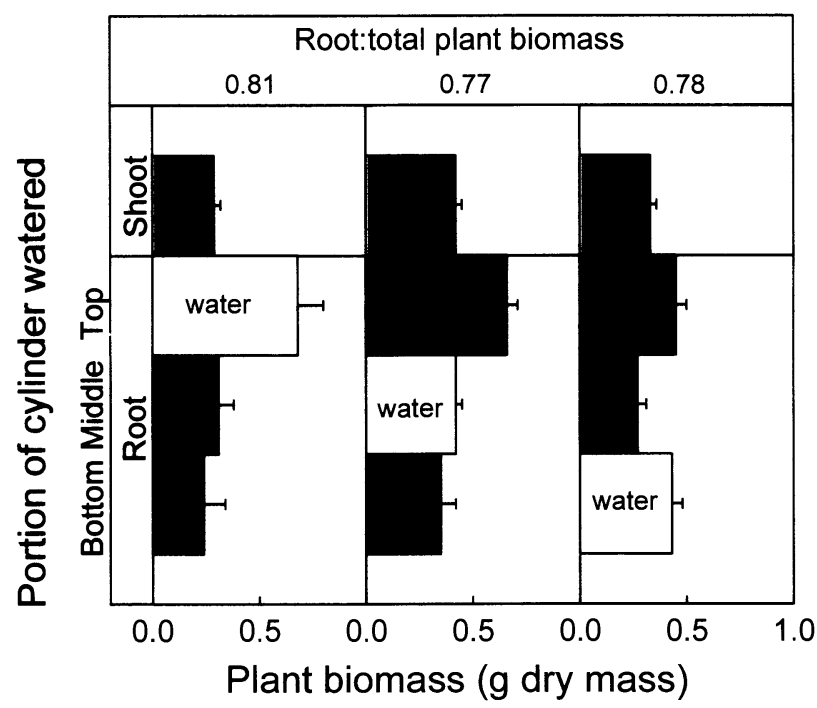

Fig. 5 Biomass distribution for Pinus ponderosa seedlings watered (open bar) at three soil depths in a 1-m-long cylinder. Mean total root biomass was similar for all treatments. Mean total shoot mass was significantly greater $(\alpha \leq 0.05)$ only for seedlings watered at $0.3 \mathrm{~m}$. Root biomass and length were significantly greater in watered soil sections than unwatered sections among treatments. The upper root biomass section for all three treatments is greater than the deeper root sections because it included the seedling root collar. Each bar represents the mean of 15 seedlings \pm 1 standard error of the mean. 


\section{Discussion}

Plant species that initiate spring growth earlier than potentially competing vegetation have higher survival and productivity because of greater access to limited resources (Harris 1967; Harris and Wilson 1970; Grime 1979; Reichenberger and Pyke 1990). Agropyron spicatum initiated growth 1-2 mo before Pinus ponderosa seedlings germinated and completed its aboveground growth within the following 3 mo. Agropyron spicatum exhibited midsummer dormancy and regrowth after fall precipitation. Apparently, A. spicatum utilized water before other species became physiologically active, thereby gaining a competitive advantage in capturing this limited resource. In contrast, $P$. ponderosa seedlings appeared to rely on taproot development to utilize deeper water sources, thereby avoiding competition in the upper soil horizons where perennial bunchgrasses have the highest root density. Thus, the entire root system of pine seedlings overlaps with that of the bunchgrasses only in the spring, when soil water is still available in the upper soil horizons. This type of interspecific resource partitioning has also been described in other xeric ecosystems (Poole and Miller 1975; Wieland and Bazzaz 1975; Cody 1986; Davis and Mooney 1986; Sala et al. 1989).

Despite our observations that seedling roots extended well beyond the zone of highest bunchgrass root concentration and that the location of soil moisture had no effect on seedling growth in greenhouse tests, root overlap with $A$. spicatum in the upper $0.30 \mathrm{~m}$ of soil significantly increased $P$. ponderosa seedling mortality. Reductions in physiological and morphological characteristics in unshielded $P$. ponderosa seedlings were first observed when water potentials decreased in the upper soil. The water potential of ambient soil indicated that all seedlings should have been drought stressed by the first week in August. Stomatal conductance measurements, however, showed that seedlings with exclusion tubes showed no sign of drought stress until late August. Thus, as soil water was utilized, exclusion tubes provided an isolated soil volume that could be accessed only by the protected $P$. ponderosa seedlings. When the exclusion tubes were excavated at the termination of this study, soil within the tubes was moist in comparison with the dry soil surrounding the exclusion tubes. This would account for the higher stomatal conductance and survival of shielded seedlings. Exploitation of deeper soil water resources by $P$. ponderosa seedlings may also have been hindered by the lower moisture-holding capacity measured in the $0.3-0.5$ soil profile compared with the upper soil layers. This would have reduced the ability of $P$. ponderosa seedlings with unshielded roots to avoid direct competition for soil water with bunchgrass roots. Thus, unshielded seedlings may have been predominantly dependent on soil water in the upper soil zones that already had been heavily utilized by A. spicatum earlier in the season.

No influence of the bunchgrass overstory on $P$. ponderosa seedlings was observed in this study. Photosynthetic light response curves for seedlings acclimated to full sun in the greenhouse showed that the photosynthesis of $P$. ponderosa seedlings would not be significantly affected by a reduction in PAR of up to $70 \%$ at solar noon. Although field-grown seedlings may have had higher light saturation levels, photosynthetic rates observed for seedlings cultivated under greenhouse conditions indicate that a $10 \%$ reduction in PAR caused by a bunchgrass canopy would have little effect on carbon gain for seedlings. However, this degree of shading could have been beneficial by providing a microenvironment of cooler temperatures around seedlings and reducing respiration and evapotranspiration rates (Gates 1963). The interaction of high soil surface temperatures with drought stress may be responsible for a relatively high level of midsummer seedling mortality (Kolb and Robberecht 1996).

The Pinus ponderosa/Agropyron spicatum community appears well suited for establishment and persistence on xeric forest communities in the northwestern United States. Provided that sufficient soil depth exists for both species to exploit their respective resource pools, this community may represent a relatively stable coexistence with one species, $A$. spicatum, dominating the upper soil zone and the other, $P$. ponderosa, utilizing deeper soils. Although competition during the later stages of forest development is also important, our study focused on the interaction between newly established pine seedlings and mature bunchgrasses because the $P$. ponderosa component appears to be highly influenced by this stage in pine/ bunchgrass communities. Extensive utilization and partitioning of soil resources by the species of a plant community indicate a high degree of coevolution (Parrish and Bazzaz 1976; Halpern 1988). On xeric sites with relatively shallow soils, competition for soil water between pine seedlings and established bunchgrasses may decrease the success of $P$. ponderosa seedling establishment. In environments where deeper soils are present, $P$. ponderosa seedlings can explore the soil to greater depths and eventually become dominant in a community composed of a tree overstory and an understory of bunchgrasses (Cooper et al. 1987).

\section{Acknowledgments}

We wish to thank R. Alan Black at Washington State University, Pullman, John Marshall, and John Hammel at the University of Idaho for reviewing this article. Funding was provided by the McIntire-Stennis Cooperative Forestry Research Program through the University of Idaho. Contribution no. 798 of the Idaho Forest, Wildlife and Range Experiment Station, College of Forestry, Wildlife and Range Sciences, University of Idaho. 


\section{Literature cited}

$\rightarrow$ Allen EB, MF Allen 1986 Water relations of xeric grasses in the field: interactions of mycorrhizas and competition. New Phytol 104:559-571.

$\rightarrow$ Allen RB, WG Lee 1989 Seedling establishment microsites of exotic conifers in Chionochloa rigida tussock grasslands, Otago, New Zealand. NZ J Bot 27:491-498.

Barker RJ 1981 Soil survey of Latah County area, Idaho. USDA Soil Conservation Service, University of Idaho, Idaho Soil Conservation Commission.

$\rightarrow$ Barkworth ME, DR Dewey 1985 Genomically based genera in the perennial Triticeae of North America: identification and membership. Am J Bot 72:767-776.

$\rightarrow$ Belsky AJ, RG Amundson, JM Duxbury, SJ Riha, AR Ali, SM Mwonga 1989 The effects of trees on their physical, chemical, and biological environments in a semi-arid savanna in Kenya. J Appl Ecol 26:1005-1024.

Bingham GE, PI Coyne, RB Kennedy, WL Jackson 1980 Design and fabrication of a portable minicuvette system for measuring leaf photosynthesis and stomatal conductance under controlled conditions. Lawrence Livermore Laboratory, University of California, Livermore.

Caldwell MM 1988 Plant root systems and competition. Pages 385404 in W Greuter, B Zimmer, eds. Proceedings of the XIV International Botanical Congress. Koeltz, Königstein/Taunus, Germany.

Caldwell MM, JH Richards 1986 Competing root systems: morphology and models of absorption. Pages 251-273 in TJ Givnish, ed. On the economy of plant form and function. Cambridge University Press, New York.

$\rightarrow$ Christy EJ 1986 Effect of root competition and shading on growth of suppressed western hemlock (Tsuga heterophylla). Vegetatio 65:21-28.

Cody ML 1986 Structural niches in plant communities. Pages 381405 in J Diamond, TJ Case, eds. Community ecology. Harper \& Row, New York.

$\rightarrow$ Cook SJ, D Ratcliff 1984 A study of the effects of root and shoot competition on the growth of green panic (Panicum maximum var. trichkoglume) seedlings in an existing grassland using root exclusion tubes. J Appl Ecol 21:971-982.

Cooper SV, KE Neiman, R Steele, DW Roberts 1987 Forest habitat types of northern Idaho: a second approximation. USDA Forest Service Intermountain Forest Experimental Station General Technical Report INT-236, Moscow, Idaho.

$\rightarrow$ Daubenmire R 1943 Vegetational zonation in the Rocky Mountains. Bot Rev 9:325-393.

$\rightarrow$ Daubenmire RF 1968 Soil moisture in relation to vegetation distribution in the mountains of northern Idaho. Ecology 49:431-438.

$\rightarrow$ Davis SD, HA Mooney 1986 Water use patterns of four co-occurring chaparral shrubs. Oecologia 70:172-177.

$\rightarrow$ DeLucia EH, SA Heckathorn 1989 The effect of drought on wateruse efficiency in a contrasting Great Basin desert and Sierran montane species. Plant Cell Environ 12:935-940.

$\rightarrow$ DeLucia EH, WH Schlesinger 1991 Resource-use efficiency and drought tolerance on adjacent great basin and Sierran plants. Ecology 72:51-58.

$\rightarrow$ DeLucia EH, WH Schlesinger, WD Billings 1988 Water relations and the maintenance of Sierran conifers on hydrothermally altered rock. Ecology 69:303-311.

$\rightarrow$ Dunn OJ 1961 Multiple comparisons among means. J Am Stat Assoc 56:52-64.

$\rightarrow$ Eissenstat DM, MM Caldwell 1988 Competitive ability is linked to rates of water extraction. Oecologia 75:1-7.

$\rightarrow$ Fonteyn PJ, BE Mahall 1981 An experimental analysis of structure in a desert plant community. J Ecol 69:883-896.

$\rightarrow$ Franco AC, PS Nobel 1990 Influences of root distribution and growth on predicted water uptake and interspecific competition. Oecologia 82:151-157.

$\rightarrow$ Frost WE, NK McDougald 1989 Tree canopy effects on herbaceous production of annual rangeland during drought. J Range Manage 42:281-283.
Gates DM 1963 Leaf temperature and transpiration. Agron J 55: 273-277.

$\rightarrow$ Gordon DR, JM Welker, JW Menke, KJ Rice 1989 Competition for soil water between annual plants and blue oak (Quercus douglasii) seedlings. Oecologia 79:533-541.

$\rightarrow$ Grime JP 1977 Evidence for the existence of three primary strategies in plants and its relevance to ecological and evolutionary theory. Am Nat 111:1169-1194.

1979 Plant strategies and vegetation processes. Wiley, London. 222 pp.

$\rightarrow$ Halpern CB 1988 Early successional pathways and the resistance and resilience of forest communities. Ecology 69:1703-1715.

Harper JL 1977 Population biology of plants. Academic Press, New York. $892 \mathrm{pp}$.

$\rightarrow$ Harris GA 1967 Some competitive relationships between Agropyron spicatum and Bromus tectorum. Ecol Monogr 37:89-111.

$\rightarrow$ Harris GA, AM Wilson 1970 Competition for moisture among seedlings of annual and perennial grasses as influenced by root elongation at low temperature. Ecology 51:530-534.

$\rightarrow$ Jackson PA, GC Spomer 1979 Biophysical adaptations of four western conifers to habit water conditions. Bot Gaz 140:428-432.

$\rightarrow$ Jacquart EM, TV Armentano 1992 Spatial and temporal tree responses to water stress in an old-growth deciduous forest. Am Midl Nat 127:159-171.

$\rightarrow$ Kolb PK, R Robberecht 1996 High temperature and drought stress effects on the survival of Pinus ponderosa seedlings. Tree Physiol, vol 16 (in press).

$\rightarrow$ Miller TE, PA Werner 1987 Competitive effects and responses between plant species in a first-year old-field community. Ecology 68:1201-1210.

Newman EI 1983 Interaction between plants. Pages 679-705 in OL Lange, ed. Physiological plant ecology. Vol 3. Springer-Verlag, New York.

$\rightarrow$ Nobel PS 1989 Temperature, water availability, and nutrient levels at various soil depths-consequences for shallow-rooted desert succulents, including nurse plant effects. Am J Bot 76:1486-1492.

$\rightarrow$ Parrish JAD, FA Bazzaz 1976 Underground niche separation in successional plants. Ecology 57:1281-1288.

$\longrightarrow 1982$ Competitive interactions in plant communities of different successional ages. Ecology 63:314-320.

$\rightarrow$ Peterson TD 1988 Effects of interference from Calamagrostis rubescence on size distributions in stands of Pinus ponderosa. $\mathrm{J}$ Appl Ecol 25:265-272.

$\rightarrow$ Poole DK, PC Miller 1975 Water relations of selected species of chaparral and coastal sage communities. Ecology 56:1118-1128.

$\rightarrow$ Reichenberger G, DA Pyke 1990 Impact of early root competition on fitness components of four semiarid species. Oecologia 85: 159-166.

Riegel GM, RF Miller, WC Krueger 1991 Understory vegetation response to increasing water and nitrogen levels in a Pinus ponderosa forest in northeastern Oregon. Northwest Sci 65:10-15.

$\longrightarrow 1992$ Competition for resources between understory vegetation and overstory Pinus ponderosa in northeastern Oregon. Ecol Appl 2:71-85.

$\rightarrow$ Robberecht R, BE Mahall, PS Nobel 1983 Experimental removal of intraspecific competitors-effects on water relations and productivity of a desert bunchgrass, Hilaria rigida. Oecologia 60:2124.

$\rightarrow$ Sala OE, RA Golluscio, WK Lauenroth, A Soriano 1989 Resource partitioning between shrubs and grasses in the Patagonian steppe. Oecologia 81:501-505.

$\rightarrow$ Shainsky LJ, SR Radosevich 1986 Growth and water relations of Pinus ponderosa seedlings in competitive regimes with Arctostaphylos patula seedlings. J Appl Ecol 23:957-966.

$\longrightarrow 1992$ Mechanisms of competition between Douglas-fir and redalder seedlings. Ecology 73:30-45.

$\rightarrow$ Shreve F 1931 Physical conditions in sun and shade. Ecology 12: 96-104.

Smith WK 1985 Montane forests. Pages 95-126 in BF Chabot, HA Mooney, eds. Physiological ecology of North American plant communities. Chapman \& Hall, New York. 
$\rightarrow$ Snaydon RW, CD Howe 1986 Root and shoot competition between established ryegrass and invading grass seedlings. J Appl Ecol 23: 667-674.

Tilman D 1982 Resource competition and community structure. Princeton University Press, Princeton, N.J. 296 pp.

$\rightarrow 1989$ Competition, nutrient reduction and the competitive neighborhood of a bunchgrass. Funct Ecol 3:215-219.

$\rightarrow$ Turner RM, SM Alcorn, G Olin, JA Booth 1966 The influence of shade, soil, and water on saguaro seedling establishment. Bot Gaz 127:95-102.

Whittaker RH 1975 Communities and ecosystems. 2d ed. Macmillan, New York. 162 pp.

$\rightarrow$ Wieland NK, FA Bazzaz 1975 Physiological ecology of three codominant successional annuals. Ecology 56:681-688.

$\rightarrow$ Wilson JB 1989 Root competition between three upland grasses. Funct Ecol 3:447-451. 